\title{
The mechanical property, degradation and cytocompatibility analysis of novel phosphate glass fibre textile
}

Chenkai Zhu ${ }^{a b}$, Ifty Ahmed $^{c}$, Andrew Parsons ${ }^{d}$, Jinsong Liu ${ }^{e}$, Xiaoling Liu $^{a b *}$

a. Ningbo Nottingham International Academy for the Marine Economy and Technology, The University of Nottingham Ningbo China, Ningbo, 315100, China

b. Ningbo Nottingham New Materials Institute, The University of Nottingham Ningbo China, Ningbo, 315100, China

c. Advanced Materials Research Group, Faculty of Engineering, University of Nottingham, Nottingham, NG7 2RD, UK

d. Composites Research Group, Faculty of Engineering, University of Nottingham, Nottingham, NG7 2RD, UK

e. Department of Technology, Sinoma Co., Ltd.,198 Tongtian Road, Nanjing, 211100, China

* Corresponding author at: Room 445, Science and Engineering Building, The University of Nottingham Ningbo China, Ningbo, 315100, China.

Tel: $+86(0) 57488180000($ ext 8057)

Email address: Xiaoling.Liu@nottingham.edu.cn 


\begin{abstract}
Phosphate glass fibres have been widely considered as potential biomedical materials for the orthopedical application due to full degradability and excellent cytocompatibility. In this study, phosphate based glass fibres were drawn from the glass system $48 \mathrm{P}_{2} \mathrm{O}_{5}-12 \mathrm{~B}_{2} \mathrm{O}_{3}-14 \mathrm{CaO}-20 \mathrm{MgO}-1 \mathrm{Na}_{2} \mathrm{O}-5 \mathrm{Fe}_{2} \mathrm{O}_{3}$, via a melt-drawn spinning process and then woven into textile fabric using a small lab-scale inkle loom. The annealing treatment was applied to both fibres and textiles with 1-hour heat treatment at $540{ }^{\circ} \mathrm{C}$, which was $10{ }^{\circ} \mathrm{C}$ above glass transition temperature. An increase in Young's modulus was observed for the single filament fibres and a decrease in tensile strength with annealing treatment. During the degradation period, the tensile strength of non-annealed fibres (N-fibre) presented a decrease by day 28, whilst annealed fibres (A-fibre) had increased by day 7 , then decreased by day 28, which was suggested to be due to the peeling effect observed on the surface of the fibres. The cytocompatibility of the textile fabric with annealing treatment (A-textile) and non-annealed (N-textile) was characterised via seeding of MG63 cells. Higher metabolic activity and DNA concentration were obtained for the A-textile samples when compared to $\mathrm{N}$-textile, which was suggested to be due to the lower dissolution rate of the A-textile resulting in fewer ions leached into the solution. The phosphate glass fibre textiles investigated in this study have shown potential application as bioresorbable composites reinforcement for orthopaedic treatment.
\end{abstract}

Keywords: Phosphate Glass Fibres; Textile; Mechanical Properties; Degradation; Cytocompatibility. 


\section{INTRODUCTION}

Silicate based Bioglass ${ }^{\circledR}$ represents a group of surface-active silica based synthetic biomaterials. The main Bioglass ${ }^{\circledR}$ components include $\mathrm{SiO}_{2}, \mathrm{Na}_{2} \mathrm{O}, \mathrm{CaO}$ and $\mathrm{P}_{2} \mathrm{O}_{5}$, and have been developed to achieve the desired biological response with bone tissue ${ }^{1}$. However, the main structural $\mathrm{SiO}_{2}$ units present long-term degradation behaviour ${ }^{2}$, thus the long-term beneficial outcome of treatment with Bioglass ${ }^{\circledR}$ implant is still under follow-up ${ }^{3}$.

Phosphate based glasses have been widely considered as potential materials for the repair and reconstruction of bone ${ }^{4-6}$. Their hydrolytic degradation rate can be varied from hours to months by simply changing the glass composition and the composition can closely match that of the inorganic phase of bone ${ }^{7-9}$. Many phosphate glass formulations have been synthesised which are cytocompatible and subtle alterations to their composition permits a wide variation of mechanical and thermal properties ${ }^{10-12}$. Ahmed et al. ${ }^{13}$ investigated phosphate based glasses in the system $40 \mathrm{P}_{2} \mathrm{O}_{5}-25 \mathrm{CaO}-$ $20 \mathrm{MgO}-15 \mathrm{Na}_{2} \mathrm{O}$ which showed a good cellular response. Phosphate glass fibres can be fabricated conventionally via a melt-drawn system, where fibres are drawn from a high temperature glass liquid and collected on a rotating drum ${ }^{14}$, Hasan et al. ${ }^{15}$ developed the system $45 \mathrm{P}_{2} \mathrm{O}_{5}-16 \mathrm{CaO}-24 \mathrm{MgO}-11 \mathrm{Na}_{2} \mathrm{O}-4 \mathrm{Fe}_{2} \mathrm{O}_{3}$, which revealed good cytocompatibility and was successful for continuous fibre drawing.

However, most of phosphate glass fibres investigated were produced only in single filament form at lab-scale quantities (grams) ${ }^{14,16}$. Single filament fibres limit the use of these fibres as they are mainly converted into non-woven random or unidirectional fibre mats ${ }^{17,18}$. To overcome this limitation, Zhu. et al ${ }^{19}$ developed a novel phosphate glass system via the addition of $\mathrm{B}_{2} \mathrm{O}_{3}$ into the phosphate glass structure to improve thermal stability and fibre drawing performance. This allowed for the 
manufacture of multifilament fibres suitable for weaving. Furthermore, a small labscale textile weaving process was developed based on the inkle-loom. As such, small pieces of phosphate glass textiles could be produced, and potentially used for an orthopaedic application such as reinforcement for bioresorable polymer bone plate

The aim of this study was to evaluate the cytocompatibility of recently developed phosphate glass fibre textiles from glass formulation $48 \mathrm{P}_{2} \mathrm{O}_{5}-12 \mathrm{~B}_{2} \mathrm{O}_{3}-14 \mathrm{CaO}-20 \mathrm{MgO}-$ $1 \mathrm{Na}_{2} \mathrm{O}-5 \mathrm{Fe}_{2} \mathrm{O}_{3}$. The effect of annealing treatment on the dissolution behavior, mechanical properties of the glass fibres and in vitro cytocompatibility were also characterised. Cytocompatibility was performed using osteosarcoma MG63 cell lines.

\section{MATERIAL AND METHOD}

\section{Phospahte glass fibre manufacture}

Phosphate based glass of composition $48 \mathrm{P}_{2} \mathrm{O}_{5}-12 \mathrm{~B}_{2} \mathrm{O}_{3}-14 \mathrm{CaO}-20 \mathrm{MgO}-1 \mathrm{Na}_{2} \mathrm{O}-$ $5 \mathrm{Fe}_{2} \mathrm{O}_{3}$ was manufactured at Sinoma Co., Ltd (China). Phosphorous pentoxide $\left(\mathrm{P}_{2} \mathrm{O}_{5}\right)$, boric acid $\left(\mathrm{H}_{3} \mathrm{BO}_{3}\right)$, calcium hydrogen phosphate dihydrate $\left(\mathrm{CaHPO}_{4} \cdot 2 \mathrm{H}_{2} \mathrm{O}\right)$, magnesium hydrogen phosphate trihydrate $\left(\mathrm{MgHPO}_{4} \cdot 3 \mathrm{H}_{2} \mathrm{O}\right)$, sodium dihydrogen phosphate dihydrate $\left(\mathrm{NaH}_{2} \mathrm{PO}_{4} \cdot 2 \mathrm{H}_{2} \mathrm{O}\right)$ and iron (III)-phosphate Tetrahydrate $\left(\mathrm{FePO}_{4} \cdot 4 \mathrm{H}_{2} \mathrm{O}\right)$ were utilised and were obtained from Sinoagent Co., Ltd (China). The precursors were weighed out and placed into a large platinum crucible which was heated using a silicon carbide rod by direct thermal irradiation at $1200{ }^{\circ} \mathrm{C}$. The resulting glass was punched into small pieces for fibre drawing.

\section{Phosphate glass fibre fabrication and textile weaving}

Continuous multifilament phosphate glass fibres were drawn in industrial scale via a specific melt-drawing spinning process 20,21 . During the fibre drawing process, phosphate based glasses were added into a Pt-crucible equipped with a 50-tipped bushing that was heated by electrical power. The glasses in the crucible were held at 
$1150^{\circ} \mathrm{C}$ for 1 hour in order to melt the glass completely and the air cooling system was utilised to cool the meniscus in order to reduce the viscosity of the glass at the bushing tips. Continuous multifilament fibres were collected onto a drum at a constant drawing speed. The final strand of 50 fibres was re-wound and processed into yarns with balanced twist of 55 tpm (twist per meter) using a twisting machine (TKV216 Type, Tianchen, China).

The inkle-type loom for textile weaving in this study was produced in-house and is presented in 错误!未找到引用源。. The surface of all the pegs fixed on uprights and the surfaces of the tension bars were all polished in order to reduce the friction effect on the surface of the warp yarns. During the weaving process, the yarns were wound onto the inkle-type loom to produce a warp by wrapping the yarns around the pegs, alternatively passing over or under the top left peg (as can be seen in the 错误!未找到 引用源。 A) until a warp of sufficient width was produced. The shuttle (错误!未找 到引用源。 B) with yarns was passed through the space between the open warp and heddle warp to be the weft of textile. The resulting textile fabric was a plain weave, with each warp and weft yarn passing over and under each other, as shown in 错误!未 找到引用源。 C. Details of the parameters of the textiles are listed in 错误!未找到 引用源。。 


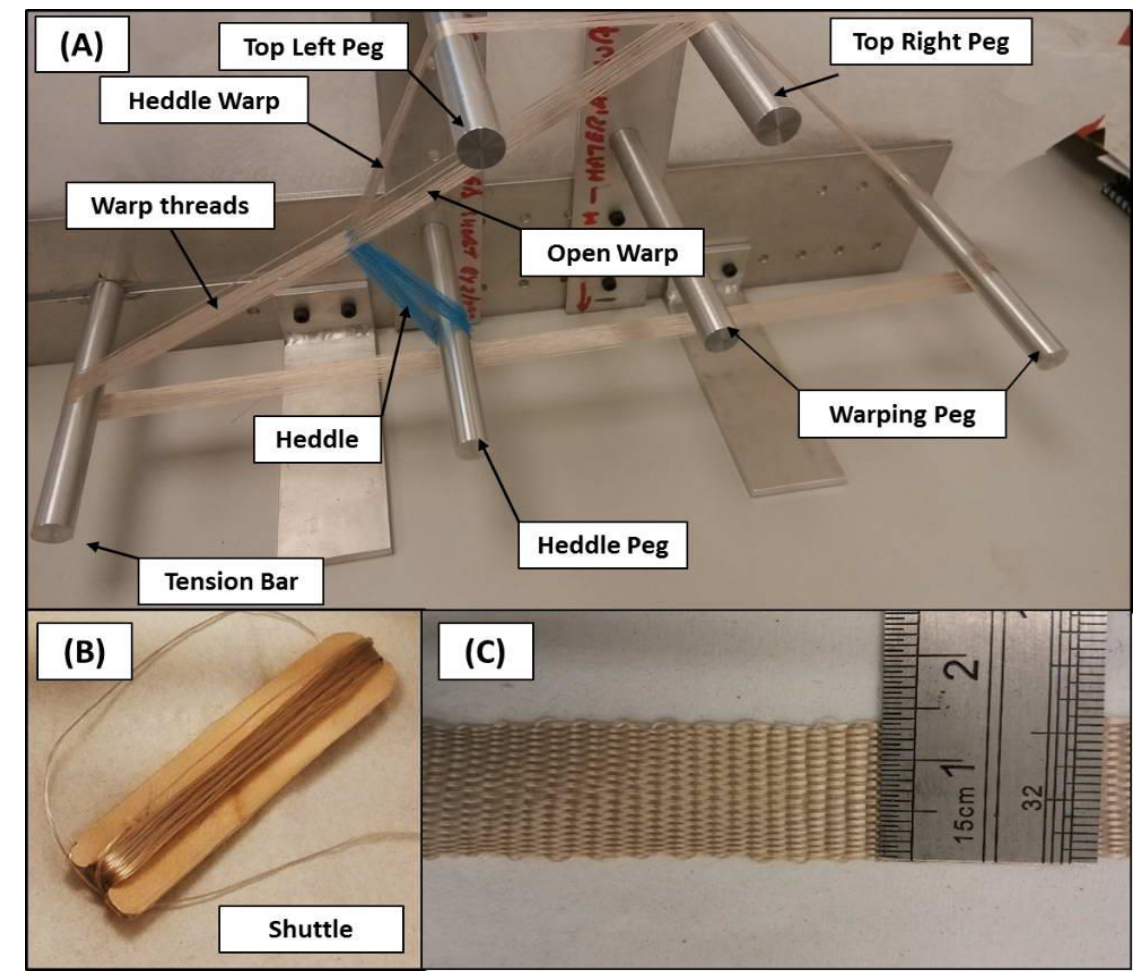

Figure 1: The image of iInkle loom for weaving textile of phosphate glass fibre (A); the image of shuttle (B) and textile woven of phosphate glass fibre (C) ${ }^{22}$.

Table 1: Geometry Parameters of the PGF textiles.

\begin{tabular}{|c|c|c|c|}
\hline Pattern & $\begin{array}{c}\text { Warp density } \\
\text { (yarns/ cm) }\end{array}$ & $\begin{array}{c}\text { Weft density } \\
\text { (yarns/cm) }\end{array}$ & $\begin{array}{c}\text { Fabric } \\
\text { thickness } \\
\text { mm }\end{array}$ \\
\hline Plain Weave & $22.7 \pm 0.2$ & $6.1 \pm 0.2$ & $0.36 \pm 0.02$ \\
\hline
\end{tabular}

\section{Heat treatment of phosphate glass fibres and textiles}

In order to investigate the influence of thermal history on the properties of fibres and textiles, they were heat treated at a temperature $\left(\mathrm{T}_{\mathrm{a}}\right)$ of $540{ }^{\circ} \mathrm{C}$, which was $10{ }^{\circ} \mathrm{C}$ above the glass transition temperature $\mathrm{T}_{\mathrm{g}}{ }^{19}$ (see Table 2). The annealing process was performed in a furnace where fibre and textile were heated from room temperature to $\mathrm{T}_{\mathrm{a}}$ at $10{ }^{\circ} \mathrm{C} / \mathrm{min}$, then held at $\mathrm{T}_{\mathrm{a}}$ for one hour before being cooled to room temperature. 
Table 2: Details of the treatment of the phosphate glass fibre and textile fabric.

\begin{tabular}{|c|c|c|c|c|}
\hline $\begin{array}{c}\text { Sample } \\
\text { code }\end{array}$ & Sample type & $\begin{array}{c}\text { Type of fibre } \\
\text { treatment }\end{array}$ & $\begin{array}{c}\text { Annealing } \\
\text { temperature }\end{array}$ & $\begin{array}{c}\text { Annealing } \\
\text { time }\end{array}$ \\
\hline N-fibre & $\begin{array}{c}\text { Single fibre } \\
\text { filament }\end{array}$ & Non-annealed & $/$ & $/$ \\
\hline A-fibre & $\begin{array}{c}\text { Single fibre } \\
\text { filament }\end{array}$ & Annealed & $540^{\circ} \mathrm{C}$ & 1 hour \\
\hline N-textile & Textile & Non-annealed & $/$ & $/$ \\
\hline A-textile & Textile & Annealed & $540^{\circ} \mathrm{C}$ & 1 hour \\
\hline
\end{tabular}

\section{Density analysis}

The density of the fibres was determined following BS $10119^{23}$ based on Archimedes' principle. A bundle of fibres ( $5 \mathrm{~g})$ was formed into a knot and placed on the specimen support of an analytical balance for weighing in air. Then the specimen support was immersed in the beaker filled with ethanol (99\%, Fisher Chemicals, UK) and the knotted fibres were weighed again immersed in ethanol. The final density of fibres $\left(\rho_{\mathrm{f}}\right)$ could be calculated by Equation ${ }^{24}$.

$\rho_{f}=\left(\frac{M_{a}}{M_{\alpha}-M_{w}}\right) \rho_{e}$

Equation 1

Where, $M_{a}$ is the mass of fibre weighed in air, $M_{w}$ is the mass of fibre immersed in ethanol and $\rho_{\mathrm{e}}$ is the density of ethanol $\left(0.82 \mathrm{~g} / \mathrm{cm}^{3}\right)$.

\section{Dissolution study of fibres}

A dissolution study was conducted on non-annealed glass fibres (N-fibre) and annealed glass fibres (A-fibre). Based on BS 10993-13 ${ }^{25}$, the fibres of each group were chopped into an average length of $50 \mathrm{~mm}$ and approximately $300 \mathrm{mg}$ fibres were placed into the middle of each individual glass vial with $30 \mathrm{ml}$ of PBS solution. The time points used were days $0,1,3,7,11,15,21$ and 28 , and three repeat samples of glass fibres were prepared for each time point. 
At each time point, the $\mathrm{pH}$ of the solution was measured using a bench-top $\mathrm{pH}$ meter (pH 212 HANNA Instruments, UK), which was calibrated using standard pH buffer solutions at pH 4.0 and $\mathrm{pH} 7.0$ (Fisher Scientific, UK) prior to each measurement. The PBS solution in the vials was withdrawn carefully by using a syringe with a $0.8 \mathrm{~mm}$ diameter needle (BD Microlance, Germany) to minimise fibre loss. Deionised water was used to refill the vials and withdrawn by the same method after gentle shaking to wash all residues of PBS from the fibres. The fibres after washing were placed into a drying oven at $50{ }^{\circ} \mathrm{C}$ for 24 hours, and the dried vials with fibre were weighed and recorded for fibre weight loss measurement. After this, fresh PBS solution was added and the degradation continued.

\section{Single filament fibre tensile test}

The single filament tensile test was carried out based on BS $11566^{26}$. For each time point, at least twenty filaments were mounted individually on plastic tabs for each fibre group, with a $25 \mathrm{~mm}$ gauge length testing setup. The ends of each fibres were bonded to the plastic tab with an acrylic adhesive (Dymax 3099, Germany), which was cured using UV light. The diameter of each fibre was measured by using a laser scan micrometer (LSM 6200, Mitutoya, Japan) which was calibrated by using glass fibre of known diameter (determined by SEM). The tensile strength of fibre was determined using a LEX810 tensile tester (Diastron, UK) at room temperature with a $0.2 \mathrm{~N}$ load cell and a speed of $0.017 \mathrm{~mm} \mathrm{~s}^{-1}$.

Scanning electron microscopy was used to observe variations in the surface morphology of the fibres after degradation. The fibres were sputter coated with platinum and examined by using a Philips XL30 Scanning electron microscope operated at $10 \mathrm{kV}$. 


\section{Cytocompatibility study}

MG63 cells (human osteosarcoma) obtained from the European Collection of Cell Cultures (ECACC) were cultured in Complete Dulbecco's Modified Eagle Medium (CDMEM) consisting of DMEM supplemented with $8.6 \%$ Foetal Bovine Serum (FBS), 1.7\% HEPES buffer, 1.7\% antibiotics-antimycotics, $0.86 \%$ glutamine, $0.86 \%$ nonessential amino acids (Gibco Invitrogen, UK) and $0.13 \mathrm{~g} / \mathrm{L}$ ascorbic acid (Sigma Aldrich, UK). The cell culture period for this study was 14 days and the four designated time points for measurement were day $1,3,7$ and 14 . The textiles were cleaned by immersion in ethanol (99\% Fisher Chemicals, UK) and then placed in the fume hood for sterilisation by UV light before cell culture. Five specimens of small textile $(10 \mathrm{~mm} \times 10 \mathrm{~mm})$ were cut from the sterilised textile and placed into the wells for analysis at each time point.

At designated time points, metabolic activity was assessed using an Alamar blue assay. Culture medium was removed from the wells and the samples were washed three times using warm PBS. $2 \mathrm{ml}$ warm Alamar Blue solution (1:10 Alamar Blue: Hanks Balanced Salt Solution (HBSS)) was added into each well and incubated for 80 minutes. $100 \mu \mathrm{l}$ aliquots from each well were transferred to a 96-well plate in triplicate and fluorescence was determined via an FLx800 plate reader (BioTek Insruments, UK) at $530 \mathrm{~nm}$ excitation and $590 \mathrm{~nm}$ emission.

Then, four of specimens were washed and cells were lysed using a freeze-thaw technique as highlighted for the method of DNA characterisation. $100 \mu$ l of Hoechst stain 33258 was added to each well (1 mg of bis-benzimide 33258 in double distilled water and diluted to 1:50 in TNE buffer) and protected in a light-proof container. 100 $\mu \mathrm{l}$ aliquots of cell lysate were transferred to a 96-well plate and mixed with $100 \mu \mathrm{l}$ Hoechst stain. Fluorescence was determined using a FLx800 plate reader at $360 \mathrm{~nm}$ 
excitation and $460 \mathrm{~nm}$ emission. DNA standards were prepared using calf thymus DNA (sigma, UK) with TNE buffer (10 mM Tris, $2 \mathrm{M} \mathrm{NaCl}$ and $1 \mathrm{mM}$ EDTA in sterile distilled water at $\mathrm{pH}$ 7.4) as a diluent. DNA concentrations were derived from a standard curve generated by the software KCjunior.

One of five specimens was used for SEM observation analysis at each time point. After being washed with warm PBS three times at $37^{\circ} \mathrm{C}$, the sample was fixed by applying a $3 \%$ glutaraldehyde in $0.1 \mathrm{M}$ cacodylate buffer for 30 minutes. Fixed sample was then washed twice using $0.2 \mathrm{M}$ cacodylate buffer and covered by $1 \%$ osmium tetroxide in PBS for 45 minutes. After that, it was dehydrated gradually using mixtures of ethanol and water from $20 \%$ to $100 \%$ ethanol in discrete $10 \%$ increments, with each step lasting 5 minutes. The final step was finished by covering sample surface with hexamethyldisilazane (HMDS) for 10 mins. All samples were sputtercoated with platinum (Polaron SC7640, UK) and observed via a scanning electron microscope (Philips XL30, UK) operatFed at $10 \mathrm{kV}$.

\section{Statistical analysis}

The average values and standard error of all data were calculated and analysed using the Prism software (version 6.0, GraphpPad Software, San Diego, CA, USA). A oneway analysis of variance (ANOVA) was calculated with the Tukey multiple post-test to compare the significance of change in one factor with time. The error bars on all the data represents standard error of mean. 


\section{RESULTS}

\section{Effect of annealing treatment on the fibres}

As can be seen from 错误!未找到引用源。, the density of the glass fibres had increased significantly after the annealing process, and the dissolution rate of the annealed fibre (A-fibre) was significantly lower $(\mathrm{P}<0.05)$ than the non-annealed fibre (N-fibre). A significant decrease $(\mathrm{P}<0.05)$ in tensile strength (from $794 \pm 41$ to $691 \pm$ $32 \mathrm{MPa}$ ) was observed after annealing (A-fibre). However, the annealed fibre (A-fibre) revealed a significantly higher modulus than non-annealed fibre $(\mathrm{P}<0.05)$. Additionally, it was observed that a higher Weibull modulus was obtained for the Afibre specimen and that this specimen also had the lower normalising strength.

Table 3: The effect of annealing treatment on the mechanical properties, density and degradation rate of phosphate glass fibres.

\begin{tabular}{|c|c|c|c|c|c|c|}
\hline $\begin{array}{l}\text { Fibre } \\
\text { Code }\end{array}$ & $\begin{array}{c}\text { Tensile } \\
\text { Strength } \\
\text { (MPa) }\end{array}$ & $\begin{array}{c}\text { Tensile } \\
\text { Modulus } \\
\text { (GPa) }\end{array}$ & $\begin{array}{l}\text { Density } \\
\left(\mathrm{kg} \mathrm{m}^{-3}\right)\end{array}$ & $\begin{array}{c}\text { Dissolution } \\
\text { rate } \\
\left(\times 10^{-8} \mathrm{~kg} \mathrm{~m}^{-}\right. \\
\left.\quad 2 \mathrm{~s}^{-1}\right)\end{array}$ & $\begin{array}{l}\text { Weibull } \\
\text { modulus }\end{array}$ & $\begin{array}{c}\text { Normalisin } \\
\text { g strength } \\
\sigma_{0} \\
\text { (MPa) }\end{array}$ \\
\hline $\mathrm{N}$-fibre & $794 \pm 41$ & $56 \pm 9$ & $2669 \pm 19$ & $1.18 \pm 0.09$ & 8.8 & 837 \\
\hline A-fibre & $691 \pm 32$ & $65 \pm 6$ & $2780 \pm 30$ & $0.48 \pm 0.04$ & 10.1 & 724 \\
\hline
\end{tabular}

\section{Retention of mechanical properties of single filament fibres during degradation}

The tensile strength and modulus values of the three fibre types, degraded in PBS at $37^{\circ} \mathrm{C}$ for up to 28 days, are shown in 错误!未找到引用源。 and 错误!未找到引用 源。. The corresponding surface morphologies of the degraded fibres observed via SEM are provided in 错误!未找到引用源。. No data is provided for the N-fibres after 15 days of degradation as they were degraded to be brittle fibres which was difficult to handle for tensile test. 


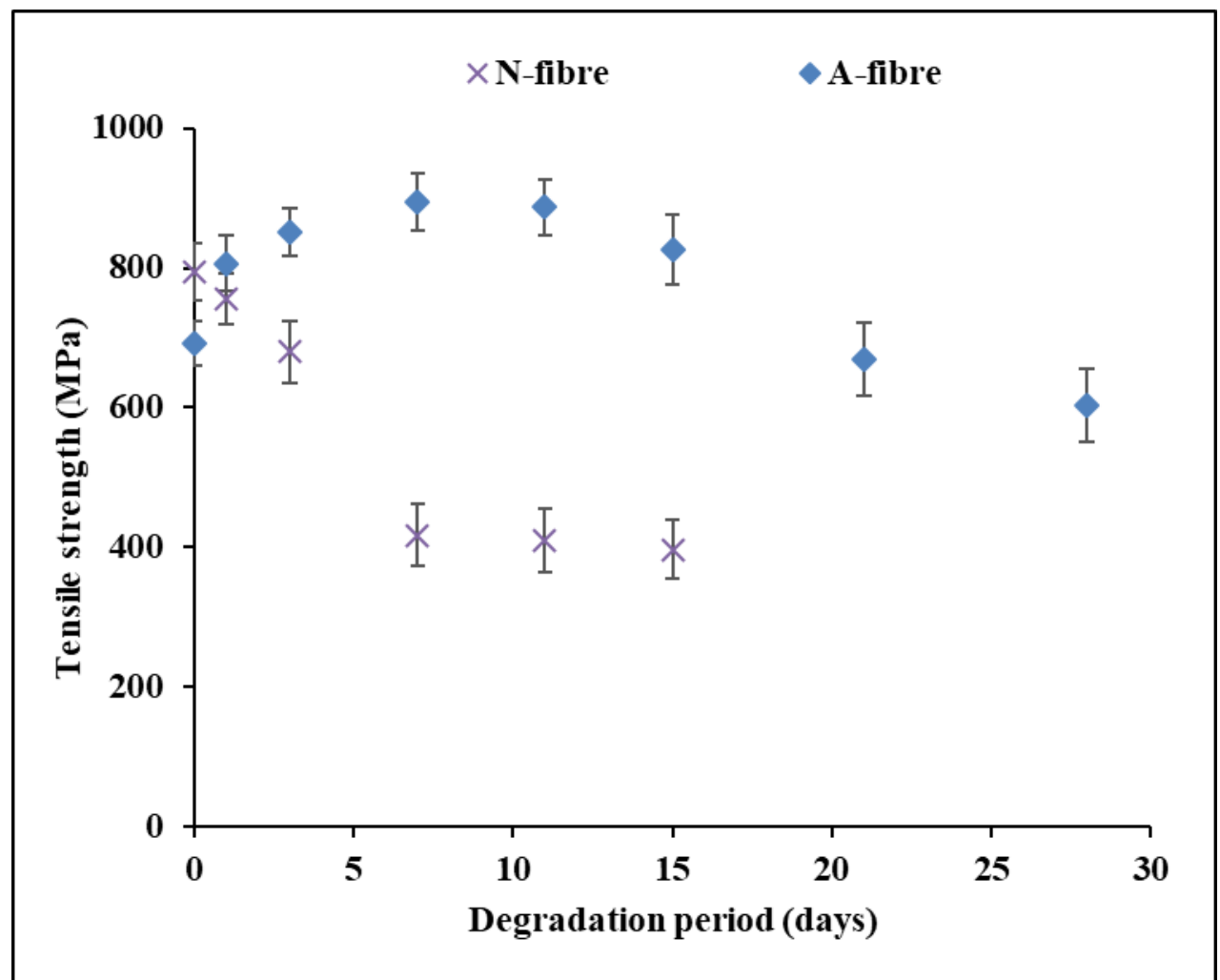

Figure 2: The change in tensile strength of the non-annealed fibre (N-fibre) and annealed fibre (A-fibre) during the degradation period. Error bars represent the standard deviation $(\mathrm{n}=20)$. 


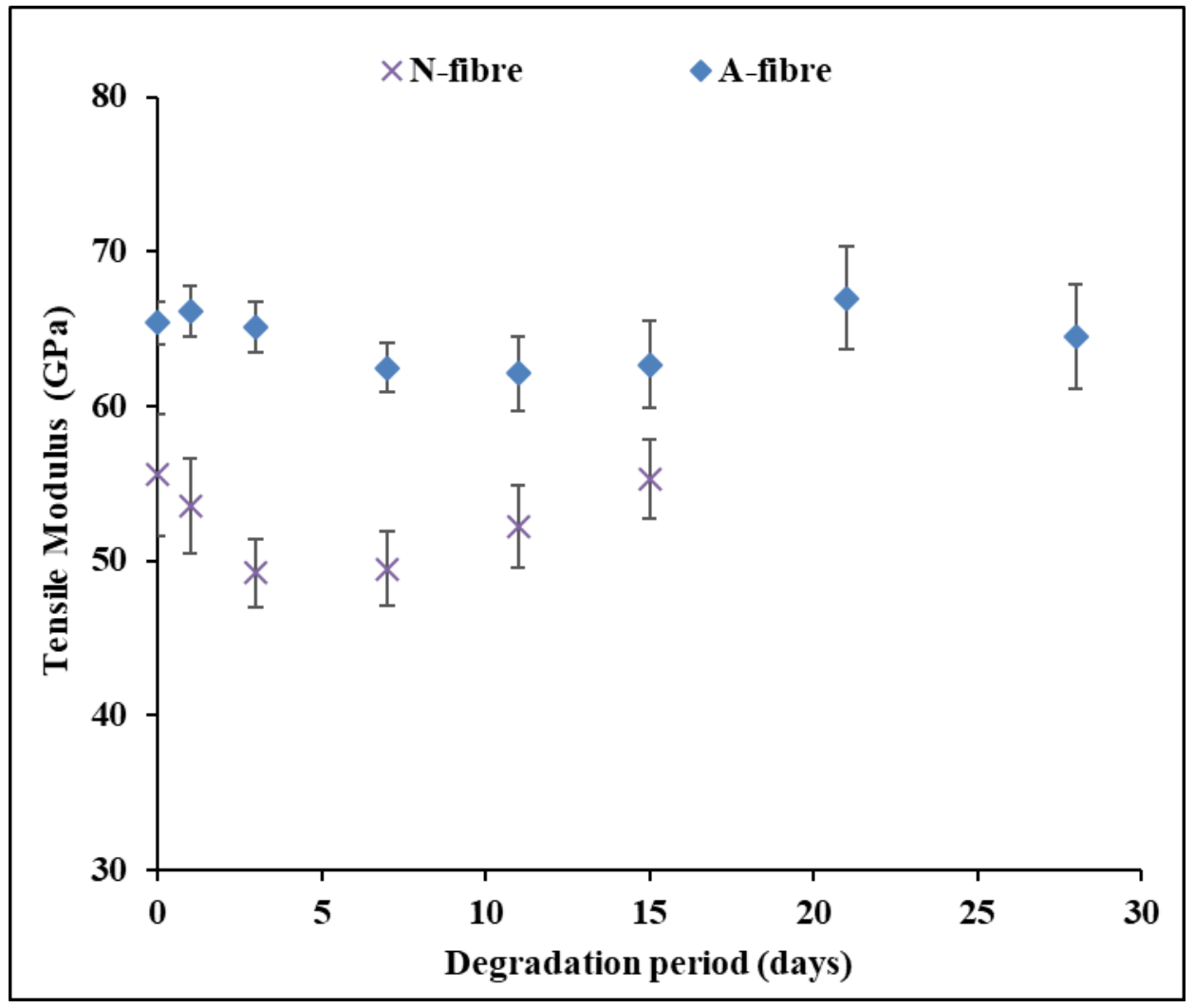

Figure 3: The change in tensile modulus of the non-annealed fibre (N-fibre) and annealed fibre (A-fibre) during the degradation period. Error bars represent the standard deviation $(\mathrm{n}=20)$.

By day 7, the tensile strength for $\mathrm{N}$-fibre was seen to decrease rapidly from $794 \pm 92$ to $410 \pm 86 \mathrm{MPa}$, whilst an increase from $690 \pm 72 \mathrm{MPa}$ to $895 \pm 91 \mathrm{MPa}$ was observed for annealed glass fibre (A-fibre). With further immersion in PBS up to 28 days, a modest reduction in tensile strength was observed for the A-fibre with a value of $603 \pm 115 \mathrm{MPa}$ at the final time point. Conversely, the $\mathrm{N}$-fibres degraded to the extent that they were too weak to test. No statistically significant $(\mathrm{P}>0.05)$ change in the tensile modulus values of either fibre type was observed over the 28 days of degradation. The tensile modulus for the $\mathrm{N}$-fibre at 15 -day was $55 \pm 3 \mathrm{GPa}$, whilst the A-fibre gave values of $65 \pm 3 \mathrm{GPa}$ after 28 days. 
The SEM images show that all the fibre types appeared to degrade by a similar mechanism, i.e. surface cracks and peeling. For the N-fibre this was apparent after only 7 days, with an obvious depth of peel seen by 15 day. The A-fibre does not seem to exhibit any cracks until 21 days and these cracks are arguably shallower than seen for the $\mathrm{N}$-fibre.

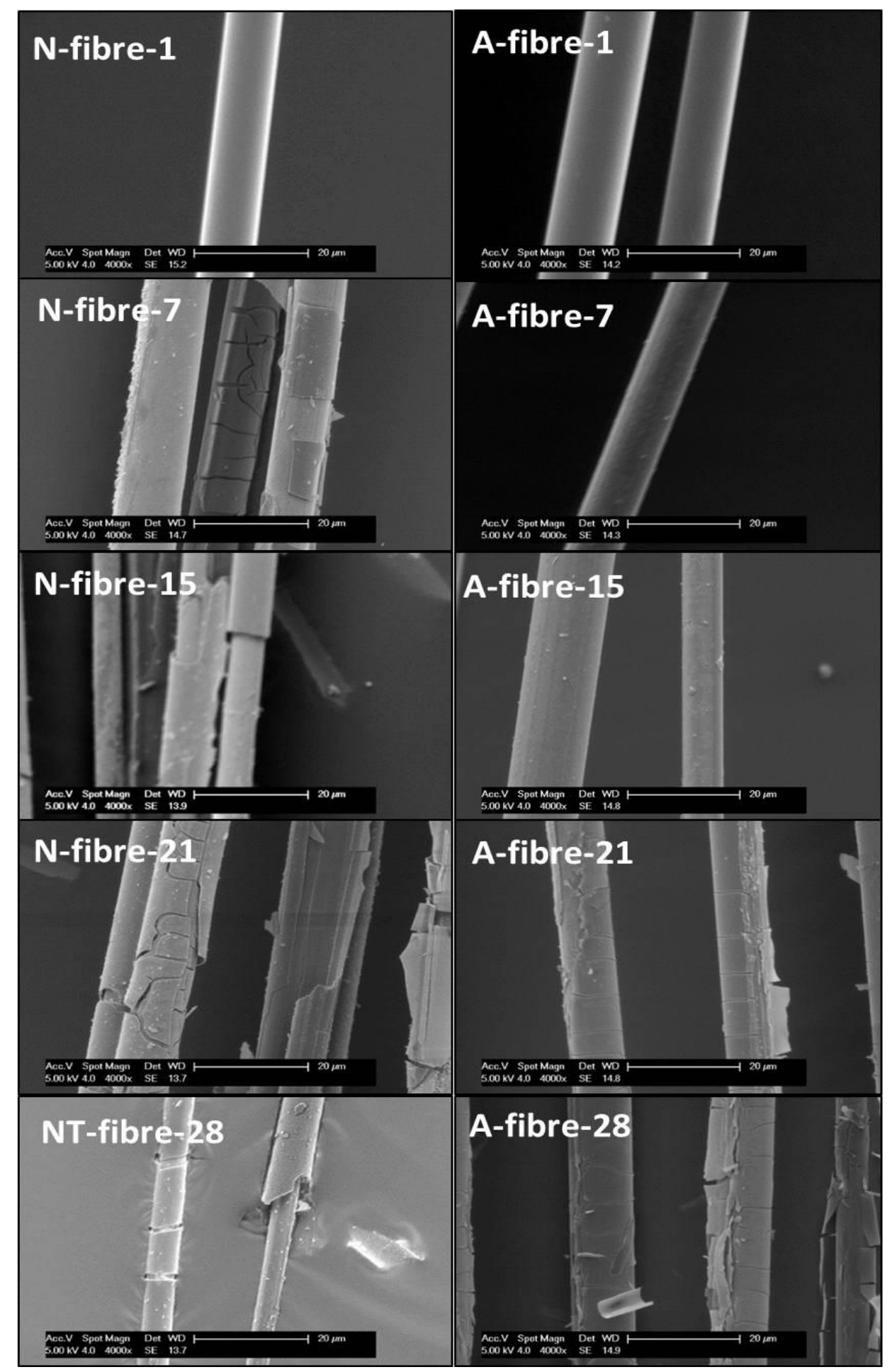


Figure 4: Scanning electron microscopy of non-annealed fibre (N-fibre) and annealed fibre (A-fibre) after degradation periods of 1, 7, 15, 21 and 28 days.

\section{Cytocompatibilty of textiles}

Overall, the metabolic activity, as determined by an Alamar blue assay, was seen to increase for both fibre types throughout the 14-day analysis period (see 错误!未找到 引用源。 $)$. A significant difference $(\mathrm{P}<0.05)$ was observed between the non-annealed textile (N-textile) and annealed textiles (A-textile) after 7 days of cell culture $(A>N)$. However, the tissue culture plastic $(\mathrm{TCP})$ control group demonstrated higher $(\mathrm{P}<0.05)$ metabolic activity at all time-points when compared to the N-textile, but no significant difference $(\mathrm{P}>0.05)$ between TCP and the A-textile was observed.

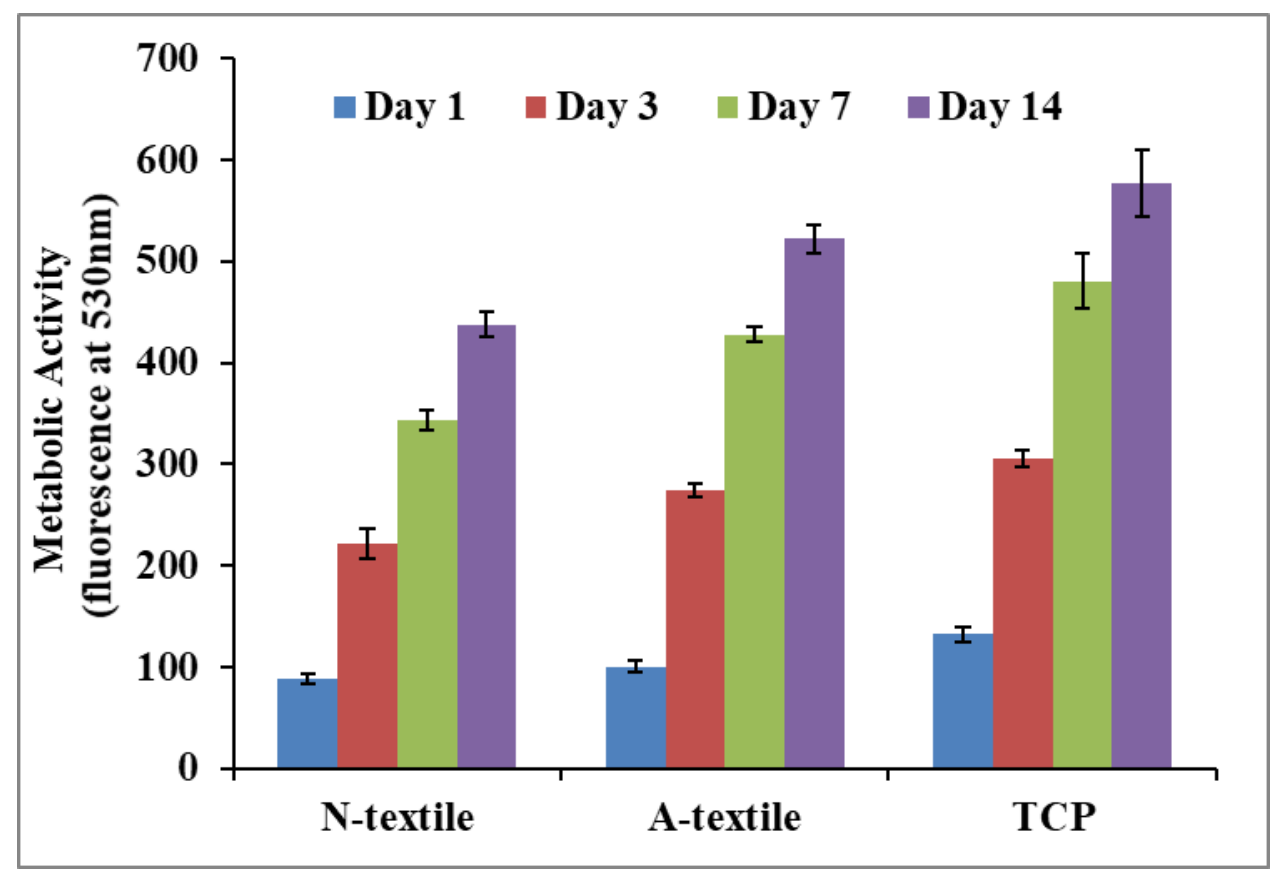

Figure 5: Metabolic activity of MG63 cells cultured on non-annealed textile (Ntextile), annealed textile (A-textile) and tissue culture plastic (TCP). Error bars represent the standard error for $\mathrm{n}=5$.

For both textile samples and the TCP control, an increase in DNA concentration was observed throughout the 14 days cell culture study. A significant difference in DNA 
concentration $(\mathrm{P}<0.05)$ was observed between the non-annealed textile $(\mathrm{N}$-textile $)$ and annealed textile (A-textile) after 3 days cell culture $(A>N)$. The TCP control exhibited significantly higher $(\mathrm{P}<0.05)$ DNA concentration when compared to the $\mathrm{N}$-textile samples at day 7 and day 14 , but no significant difference $(\mathrm{P}>0.05)$ between TCP and the A-textile was observed.

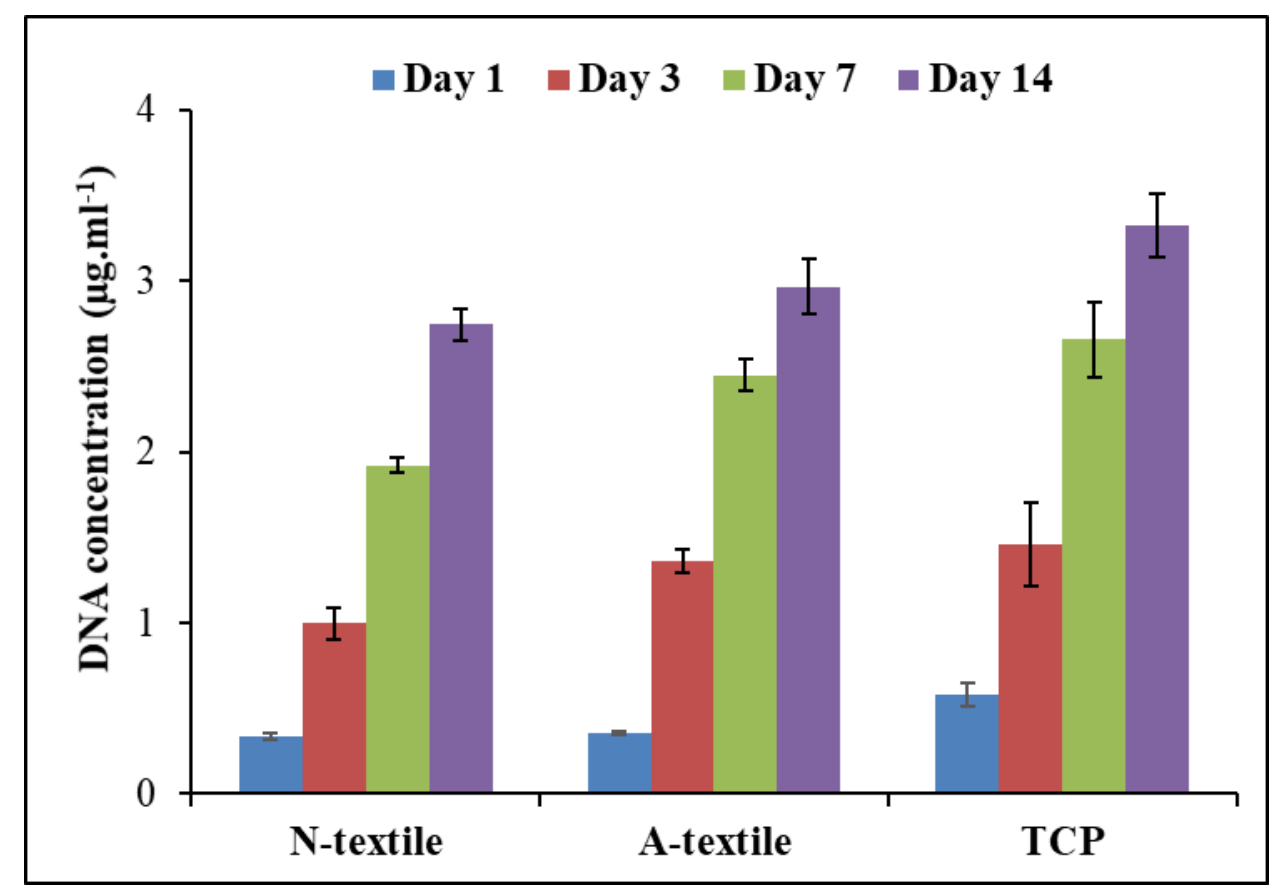

Figure 6: Proliferation of MG63 cells cultured on non-annealed textile (N-textile), annealed textile (A-textile) and tissue culture plastic (TCP). Error bars represent the standard error for $\mathrm{n}=5$.

The morphology of the MG63 cells cultured on textile samples and on the TCP control group was visualised using scanning electron microscopy (as shown in 错误! 未找到引用源。). At the early time points (1 and 3 days), the TCP control group had a greater cell density and number of attachment sites (lamellipdia and filopodia), when compared to the textile (N-textile and A-textile). Additionally, it was seen that the MG63 cells attached to the textile and grew along the longitudinal direction of the fibres. After 3 days, there were some large clusters of MG63 cells with lamellipodia 
extended to neighbouring cells. Formation of a confluent layer covering warp and weft of the textile samples was observed after 7 days of culture.

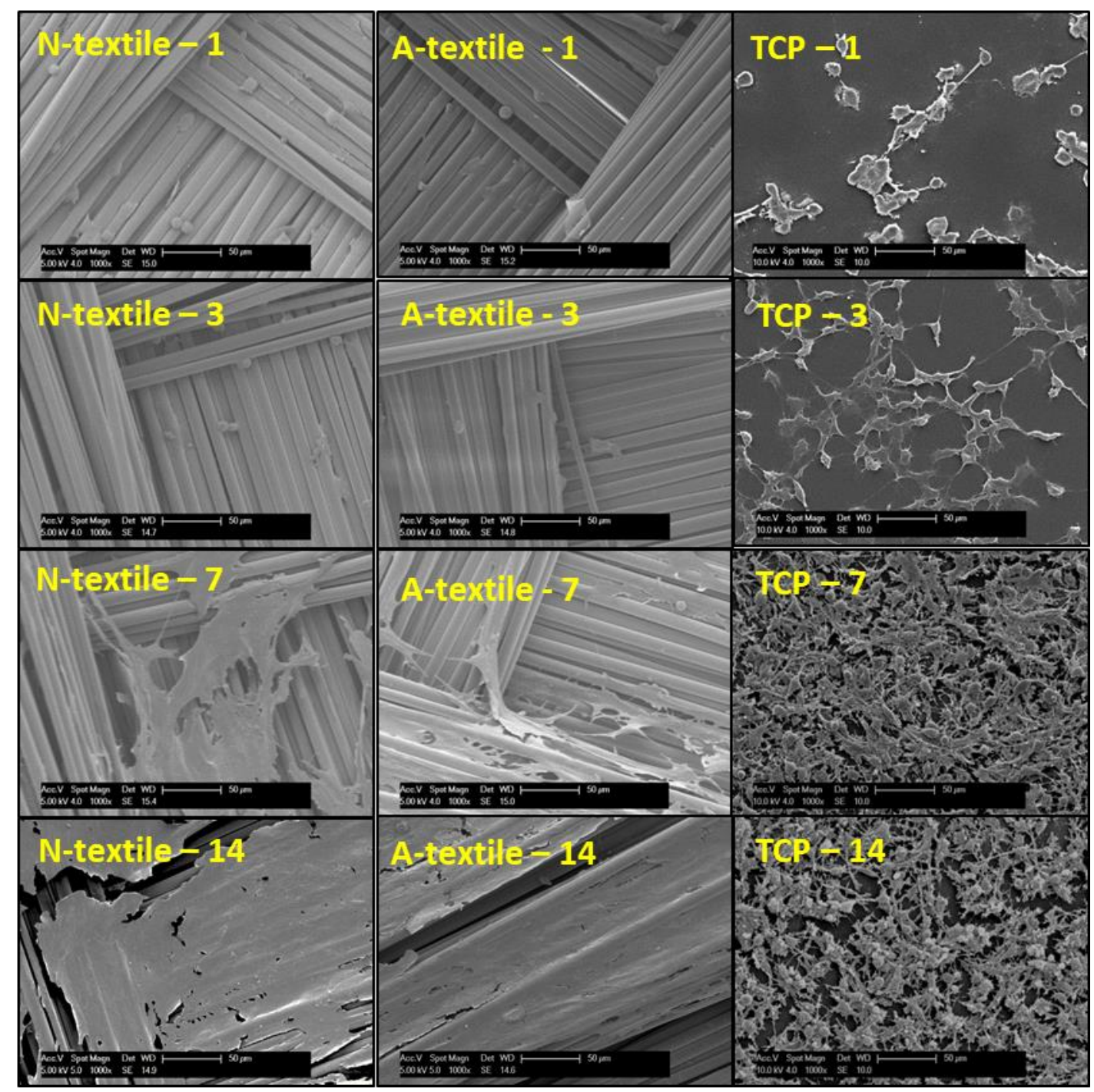

Figure 7: Scanning Electron Microscopy micrographs of MG63 cells cultured on nonannealed textile (N-textile), anneal textile (A-textile) and tissue culture plastic (TCP) at four time points: days $1,3,7$ and 14 . 


\section{DISCUSSION}

The borophosphate glass fibres characterised in this study were composition $48 \mathrm{P}_{2} \mathrm{O}_{5}-$ $12 \mathrm{~B}_{2} \mathrm{O}_{3}-14 \mathrm{CaO}-20 \mathrm{MgO}-1 \mathrm{Na}_{2} \mathrm{O}-5 \mathrm{Fe}_{2} \mathrm{O}_{3}$, of which the glass was developed and analysed in preliminary study ${ }^{19}$. However, as the fibre performance is the key in the composites, the fibre reinforcement types and fibre properties, especially the mechanical properties, degradation behaviour and cytocompatibility will demonstrate the performance of final composite products.

For the success of glass fibre drawing, the strong bonds in the glass structure are required to withstand the stresses from the pulling process at high temperature. As such, the continuity of the fibre drawing should depend on the ability of the strongest bonds to hold structure during the fibre pulling out of the molten glass ${ }^{27}$. Several studies ${ }^{28,29}$ have found the improvement of fibre drawing performance with addition of $\mathrm{Fe}_{2} \mathrm{O}_{3}$ into phosphate glass network due to the higher bonding strength of $\mathrm{Fe}-\mathrm{O}$ bond compared to P-O bond. It is also reported that the doping of $\mathrm{B}_{2} \mathrm{O}_{3}$ into the phosphate based glass could play the role of glass network former as well as $\mathrm{P}_{2} \mathrm{O}_{5}$, form the stronger P-O-B bond and improve structure stability, thus reduce the crystalline trend during the fibre drawing process ${ }^{30-32}$.

However, it is necessary to consider the cytocompatibility of the glass in fibre form as well, since it is well known that cells respond to the topology of the surface on which they attach ${ }^{33}$. Additionally, fibres present a much larger surface area to volume ratio, providing a more rapid release of degradation products into solution. As such, the cytocompatibility assessment in this study is needed to investigate the interaction between MG63 cell lines and the textile fabrics. Both non-annealed fibre (N-fibre) and annealed fibres (A-fibre) were investigated. 
A significant decrease $(\mathrm{P}<0.05)$ in tensile strength of fibres was observed after annealing treatment whilst the annealed fibre (A-fibre) revealed a significantly higher modulus than $\mathrm{N}$-fibre $(\mathrm{P}<0.05)$. The effect of annealing treatment on the mechanical properties of the fibres was studied by Murgatroyd ${ }^{27}$ and Stockhorst ${ }^{34}$ who revealed that the Young's modulus of fibre increased but the tensile strength had reduced after annealing. According to the literature ${ }^{27,35}$, the long chain of molecules within the phosphate glass backbone were suggested to have a degree of alignment in the direction of fibre drawing. The annealing process may relax the polymer chains, eliminate the structural anisotropy along the fibre axis and promote a random entangled chain configuration, as such to form a more stable structure closing to that of the bulk glass and result in enhancement in the tensile modulus of glass fibre ${ }^{14,29 \text {, }}$ 36.

As the tensile strength of fibre was attributed to the surface quality ${ }^{14}$, the loss of tensile strength was attributed to the increase of severity of flaws incurred during the annealing process ${ }^{27,36}$, for example, the ambient moisture was able to attack the glass surface during the annealing process, cleave $\mathrm{P}-\mathrm{O}-\mathrm{P}$ bonds and forming flaws on the surface which could increase the possibility of fibre break, and finally reduce the strength of the fibre ${ }^{37}$.

On the other hand, Begum et al. ${ }^{38}$ suggested that heat treatment on the bioactive glass could reduce the interatomic spaces, resulting in an increase in glass density. With the comparison between the density of the A-fibre and $\mathrm{N}$-fibre in this study, it was confirmed a denser structure of glass fibres was introduced due to the rearrangement of atomic during the annealing process, which also leaded to an increase in the modulus of fibres as can be seen in Figure 3. 
According to the Table 3, it is can be seen that the dissolution rate of glass fibre was found to decrease by $\sim 59 \%$ with annealing treatment. The annealing treatment on the durability of glass fibre was also studied by Choueka et al. ${ }^{39}$ who found the cooling and pulling process of $\mathrm{P}_{2} \mathrm{O}_{5}-\mathrm{CaO}-\mathrm{ZnO}-\mathrm{Na}_{2} \mathrm{O}$ fibres could result in frozen length of bonds, broken bonds with nonquilibrum angle, as such forming the highly moisture sensitive glass with inherent stresses which were expected to increase the degradation rate ${ }^{34,39}$. The annealing treatment at glass transition temperature $T_{g}$ could reduce the effects of stressing and improve durability via reforming bonds or rotate bonds to stable configuration. It was also confirmed by Otto ${ }^{40}$ also suggested the annealing process could achieve a more stable configuration of glass fibre and result in a compact and dense structure close to that of bulk glass ${ }^{34}$.

As can be seen in the Figure 2, the tensile strength of the N-fibres was observed to decrease rapidly during the earlier immersing period. This phenomenon was also reported by Sharmin et al ${ }^{14}$ who explained that the rapid reduction in tensile strength of non-annealed fibre was attributed to the fibre degradation, where the phosphate chains was broken down by hydrolysis after the release of alkali in aqueous. However, the trend of the tensile strength profile of annealed fibres (A-fibre) was suggested to increase up to day 7 and then decrease by day 28. More importantly, the annealed fibres were still strong enough to handle during single filament fibre tensile tests for a longer period of dissolution time, whereas the non-annealed fibres were too brittle to handle by 21 day.

Cozien-Cazuc et al. ${ }^{36}$ investigated the phosphate glass fibres and also reported an similar increase trend in tensile strength of annealed fibre during the initial period of fibre degradation in distilled water at $37{ }^{\circ} \mathrm{C}$. They suggested that the annealing treatment process could generate a surface tensile stress layer on the phosphate glass 
surface as water vapour cleaved the P-O-P chains which resulted in development of shallow surface cracks ${ }^{37,41}$. With the degradation process, the peeling off effect on the fibre surface could remove the tensile layer during the degradation as such an increase of annealed fibre was observed. As can be confirmed with SEM images in this study, the fibres were observed to degrade via delamination. Cleavage of P-O-P bonds was suggested to take place in the hydrated glass surface layer to release chains of phosphate with different degrees of polymerisation into solution ${ }^{42}$. Additionally, many studies ${ }^{43,44}$ have also described the dissolution of phosphate glass fibre via a hydration process leading to an outer hydration layer peeling off from the glass fibre surface.

On the other hand, the change in the tensile modulus of fibres was not significant during degradation, as the degradation of fibre was a surface erosion phenomenon which should not affect the glass intrinsic structure ${ }^{41,45}$.

For the cytocompatibility tests, cell density observed on the surface of the textile samples (see 错误!未找到引用源。) increased throughout the period of cell culture and the morphology of the cells showed good confluent layers covering the textile fabric both with and without heat treatment. In addition, the results in 错误!未找到引 用源。 and 错误!未找到引用源。 demonstrated that the A-textile exhibited higher $(\mathrm{P}<0.05)$ metabolic activity and DNA concentration when compared to N-textile, and no significant difference $(\mathrm{P}>0.05)$ between TCP and the A-textile was observed. Since the textiles were from the same batch, the fibres presented similar morphologies. This would suggest that differences in topology were not responsible for differences in cell behaviour. 
Considering the different effect between the annealed and non-annealed glasses on the cell, it is more likely that the ion release rates from the glass played key roles in influencing cell growth and proliferation ${ }^{46}$. It has been reported that boron concentrations below $0.65 \mathrm{mM}$ was able to support the proliferation of stem cells, whilst above $2.5 \mathrm{mM}$ produced a reduction in cell proliferation ${ }^{47,48}$. Since phosphate glasses are known to be surface eroding materials, the surface area of the material under consideration must be taken into account ${ }^{42,49}$. Although the bulk glass of $48 \mathrm{P}_{2} \mathrm{O}_{5}-12 \mathrm{~B}_{2} \mathrm{O}_{3}-14 \mathrm{CaO}-20 \mathrm{MgO}-1 \mathrm{Na}_{2} \mathrm{O}-5 \mathrm{Fe}_{2} \mathrm{O}_{3}$ presented higher metabolic activity and DNA concentration of cells when compared to TCP control in a previous study ${ }^{19}$, the textile samples, with much higher surface area to volume ratios, provided results that were only on a par with TCP.

With higher relative surface area compared to the bulk glass, the textiles would be expected to release ions into solution more rapidly. Since the cells did not perform as well as those on the bulk glass, this would suggest that the extent of ion release from the fibres provided a concentration of ions that was less favourable to cells. However, the A-textile still performed on a par with TCP, which is a good result. The results from the $\mathrm{N}$-textile were not as good, suggesting that their higher rate of ion release was unfavourable.

In summary, this study investigated the use of an annealing treatment on the mechanical properties, degradation behaviour and cell response to phosphate based glass fibres in the system $48 \mathrm{P}_{2} \mathrm{O}_{5}-12 \mathrm{~B}_{2} \mathrm{O}_{3}-14 \mathrm{CaO}-20 \mathrm{MgO}-1 \mathrm{Na}_{2} \mathrm{O}-5 \mathrm{Fe}_{2} \mathrm{O}_{3}$. The phosphate glass fibres and textile fabrics in this study have potential for use as medical woven textiles for bone fracture area fixation or reinforcement of bioresorbable composites for medical applications. 


\section{CONCLUSIONS}

In this study, the phosphate based glass fibre was drawn from the glass system $48 \mathrm{P}_{2} \mathrm{O}_{5}-12 \mathrm{~B}_{2} \mathrm{O}_{3}-14 \mathrm{CaO}-20 \mathrm{MgO}-1 \mathrm{Na}_{2} \mathrm{O}-5 \mathrm{Fe}_{2} \mathrm{O}_{3}$, and the textile fabric was plain woven by using lab made inkle loom.

The effect of annealing treatment on the glass fibre was investigated. The Young's modulus of single filament fibre was increased by $16 \%$ with annealing treatment whilst the tensile strength was reduced by $5 \%$ due to the damage on the fibre surface during the annealing process. Whilst, the tensile strength and Young's modulus of the annealed fibre (A-fibre) decreased much slower than non-annealed fibre (N-fibre) during the dissolution.

The glass fibre textile with annealing treatment (A-textile) showed significantly $(\mathrm{P}<0.05)$ higher metabolic activity and DNA concentration when compared to control group due to the annealing treatment reduce the residual stress in the fibre structure and improve the structure stability, resulting in less ions leached into the solution and lower ions concentration. The MG63 cells on textile fabric was seem to grow along the fibre of textile and become a confluence layer covering textile sample after 14 days of cell culture.

For future study, it is worth to analyse the ions release from the textile, figure out the valve value of the ions concentration of solution for cell growth and proliferation. With the good cytocompatibility, the textile of phosphate glass fibre presented potential application for orthopaedic treatment.

\section{ACKNOWLEDGEMENTS}

The authors would like to thank Sinoma Co.,Ltd (China) for kindly providing glass fibres for this study. Additionally, authors also would like to appreciate the financial supported by Ningbo S\&T bureau Ningbo International Collaboration Project (project 
code 2017D10012), and Ningbo 3315 Innovation team Scheme "Composites

Development and Manufacturing for Sustainable Environment”.

\section{Declaration of Conflicting Interests}

The authors wish to confirm that there are no known conflicts of interest associated with this publication.

\section{REFERENCES}

1. Helsen J, Proost J, Schrooten J, Timmermans G, Brauns E and Vanderstraeten J. Glasses and bioglasses: synthesis and coatings. Journal of the European Ceramic Society. 1997; 17: 147-52.

2. Franks K, Abrahams I and Knowles J. Development of soluble glasses for biomedical use Part I: In vitro solubility measurement. Journal of Materials Science: Materials in Medicine. 2000; 11: 609-14.

3. Lindfors NC, Hyvönen P, Nyyssönen M, et al. Bioactive glass S53P4 as bone graft substitute in treatment of osteomyelitis. Bone. 2010; 47: 212-8.

4. Brow RK. Review: the structure of simple phosphate glasses. Journal of NonCrystalline Solids. 2000; 263\&264: 1-28.

5. Lee YK and LeGeros RZ. Calcium phosphate glass: potential as biomaterial for hard tissue repair. Key Engineering Materials. 2008; 377: 43-72.

6. Ahmed I, Ready D, Wilson M and Knowles JC. Antimicrobial effect of silverdoped phosphate-based glasses. Journal of biomedical materials research Part A. 2006; 79: 618-26.

7. Abou Neel E, Ahmed I, Pratten J, Nazhat SN and Knowles JC. Characterisation of antibacterial copper releasing degradable phosphate glass fibres. Biomaterials. 2005; 26: 2247-54.

8. Abou Neel EA, Ahmed I, Blaker JJ, et al. Effect of iron on the surface, degradation and ion release properties of phosphate-based glass fibres. Acta biomaterialia. 2005; 1: 553-63.

9. Abou Neel EA, Ahmed I and Knowles JC. Investigation of the mixed alkali effect in a range of phosphate glasses. Key Engineering Materials. 2007; 330-332: $161-4$.

10. Ahmed I, Parsons AJ, Palmer G, Knowles JC, Walker GS and Rudd CD. Weight loss, ion release and initial mechanical properties of a binary calcium phosphate glass fibre/PCL composite. Acta biomaterialia. 2008; 4: 1307-14.

11. Abou Neel EA and Knowles JC. Physical and biocompatibility studies of novel titanium dioxide doped phosphate-based glasses for bone tissue engineering applications. Journal of materials science Materials in medicine. 2008; 19: 377-86.

12. Parsons AJ, Evans M, Rudd CD and Scotchford CA. Synthesis and degradation of sodium iron phosphate glasses and their in vitro cell response. Journal of biomedical materials research Part A. 2004; 71: 283-91.

13. Ahmed I, Parsons A, Jones A, Walker G, Scotchford C and Rudd C. Cytocompatibility and effect of increasing $\mathrm{MgO}$ content in a range of quaternary invert phosphate-based glasses. Journal of biomaterials applications. 2010; 24: 55575 . 
14. Sharmin N, Parsons AJ, Rudd CD and Ahmed I. Effect of boron oxide addition on fibre drawing, mechanical properties and dissolution behaviour of phosphate-based glass fibres with fixed 40, 45 and $50 \mathrm{~mol} \%$ P2O5. Journal of biomaterials applications. 2014; 0: 1-15.

15. Hasan MS, Ahmed I, Parsons AJ, Walker GS and Scotchford CA. Material characterisation and cytocompatibility assessment of quinternary phosphate glasses. Journal of materials science Materials in medicine. 2012; 23: 2531-41.

16. Hasan M, Carpenter N, Wei T, McNally D, Ahmed I and Boszczyk B. Effects of adding resorbable phosphate glass fibres and PLA to calcium phosphate bone cements. Journal of applied biomaterials \& functional materials. 2014: 0-.

17. Parsons AJ, Ahmed I, Han N, Felfel R and Rudd CD. Mimicking bone structure and function with structural composite materials. Journal of Bionic Engineering. 2010; 7: S1-S10.

18. Ahmed I, Jones I, Parsons A, et al. Composites for bone repair: phosphate glass fibre reinforced PLA with varying fibre architecture. Journal of Materials Science: Materials in Medicine. 2011; 22: 1825-34.

19. Zhu C, Ahmed I, Parsons A, et al. Structural, thermal, in vitro degradation and cytocompatibility properties of $\mathrm{P} 2 \mathrm{O} 5-\mathrm{B} 2 \mathrm{O} 3-\mathrm{CaO}-\mathrm{MgO}-\mathrm{Na} 2 \mathrm{O}-\mathrm{Fe} 2 \mathrm{O} 3$ glasses. Journal of Non-Crystalline Solids. 2017; 457: 77-85.

20. Liu J, Zu Q, Rudd C, Huang S and Liu X. The Textile Products of Cytocompatible Continuous Phosphate Glass Fibre In: Sinoma Co. L and China UoNN, (eds.). 2016.

21. Zu Q, Rudd C, Liu J, Liu X and Zhang Y. Development and Application of Bioactive Continuous Phosphate Glass Fibre Textile Reinforced Composites. In: Sinoma Co. L and Nottingham Uo, (eds.). 2016.

22. Zhu C, Ahmed I, Parsons A, et al. Novel bioresorbable phosphate glass fiber textile composites for medical applications. Polymer Composites. 2018.

23. British standard institution, carbon fibre - Determination of density. London: British Standards Institution, BS 10119: 2002, 2002.

24. Truong M, Zhong W, Boyko S and Alcock M. A comparative study on natural fibre density measurement. The Journal of The Textile Institute. 2009; 100: 525-9.

25. British Standard Institution, Biological evaluation of medical devices - Part 13: Identification and quantification of degradation products from polymeric medical devices. London: British Standards Institution, BS 10993-13: 2010, 2010.

26. Bitish standard institution, carbon fibre -Determination of the tensile properties of single-filament specimens. London: British Standards Institution, BS 11566: 1996, 1996.

27. Murgatroyd JB. The delayed elastic effect in glass fibres and the constitution of glass in fibre form. J Soc Glass Technol. 1948; 32: 291-300.

28. Sharmin N, Hasan MS, Parsons AJ, Rudd CD and Ahmed I. Cytocompatibility, mechanical and dissolution properties of high strength boron and iron oxide phosphate glass fibre reinforced bioresorbable composites. Journal of the mechanical behavior of biomedical materials. 2016; 59: 41-56.

29. Sharmin N, Rudd CD, Parsons AJ and Ahmed I. Structure, viscosity and fibre drawing properties of phosphate-based glasses: effect of boron and iron oxide addition. Journal of Materials Science. 2016; 51: 7523-35.

30. Bischoff CM. The mixed glass former effect in $0.5 \mathrm{Na} 2 \mathrm{~S}+0.5[\mathrm{xGeS} 2+(1-$ x)PS5/2] glasses. Materials Science and Engineering. Iowa State University, 2013. 
31. Christensen R, Byer J, Olson G and Martin SW. The glass transition temperature of mixed glass former $0.35 \mathrm{Na} 2 \mathrm{O}+0.65[\mathrm{xB} 2 \mathrm{O} 3+(1-\mathrm{x}) \mathrm{P} 2 \mathrm{O} 5]$ glasses. Journal of Non-Crystalline Solids. 2012; 358: 826-31.

32. Raguenet B, Tricot G, Silly G, Ribes M and Pradel A. The mixed glass former effect in twin-roller quenched lithium borophosphate glasses. Solid State Ionics. 2012; 208: 25-30.

33. Miola M, Brovarone CV, Maina $\mathrm{G}$, et al. In vitro study of manganese-doped bioactive glasses for bone regeneration. Materials Science and Engineering: C. 2014; 38: $107-18$.

34. Stockhorst H and Brückner R. Structure sensitive measurements on phosphate glass fibers. Journal of Non-Crystalline Solids. 1986; 85: 105-26.

35. Murgatroyd JB. The strength of glass fibres. part 1. elastic properties. Journal Society of Glass Technology. 1944; 28: 368-87.

36. Cozien-Cazuc S, Parsons AJ, Walker GS, Jones IA and Rudd CD. Effects of aqueous aging on the mechanical properties of $\mathrm{P} 40 \mathrm{Na} 20 \mathrm{Ca} 16 \mathrm{Mg} 24$ phosphate glass fibres. Journal of Materials Science. 2008; 43: 4834-9.

37. Hayden JS, Marker III AJ, Suratwala TI and Campbell JH. Surface tensile layer generation during thermal annealing of phosphate glass. Journal of NonCrystalline Solids. 2000; 263-264: 228-39.

38. Begum AN, Rajendran V and Ylänen H. Effect of thermal treatment on physical properties of bioactive glass. Materials chemistry and physics. 2006; 96: 409-17.

39. Choueka J, Charvet JL, Alexander H, et al. Effect of annealing temperature on the degradation of reinforcing fibers for absorbable implants. Journal of biomedical materials research. 1995; 29: 1309-15.

40. Otto WH. Compaction effects in glass fibers. Journal of the American Ceramic Society. 1961; 44: 68-72.

41. Parsons AJ, Ahmed I, Yang J, Cozien-Cazuc S and Rudd CD. Heat-treatment of phosphate glass fibres and its effect on composite property retention. 16th international conference on composite materials. 2007.

42. Bunker BC, Arnold GW and Wilder JA. Phosphate glass dissolution in aqueous solutions. Journal of Non-Crystalline Solids. 1984; 64: 291-316.

43. Rinehart JD, Taylor TD, Tian Y and Latour RA. Real-time dissolution measurement of sized and unsized calcium phosphate glass fibers. Journal of biomedical materials research. 1999; 48: 833-40.

44. Davis JR. Corrosion: Understanding the basics. ASM International, 2000.

45. Cozien-Cazuc S, Parsons AJ, Walker GS, Jones IA and Rudd CD. Real-time dissolution of $\mathrm{P} 40 \mathrm{Na} 20 \mathrm{Ca} 16 \mathrm{Mg} 24$ phosphate glass fibers. Journal of Non-Crystalline Solids. 2009; 355: 2514-21.

46. Brauer DS, Russel C, Li W and Habelitz S. Effect of degradation rates of resorbable phosphate invert glasses on in vitro osteoblast proliferation. Journal of biomedical materials research Part A. 2006; 77: 213-9.

47. $\mathrm{Fu} \mathrm{H}, \mathrm{Fu} \mathrm{Q}$, Zhou N, et al. In vitro evaluation of borate-based bioactive glass scaffolds prepared by a polymer foam replication method. Materials Science and Engineering: C. 2009; 29: 2275-81.

48. Brown RF, Rahaman MN, Dwilewicz AB, et al. Effect of borate glass composition on its conversion to hydroxyapatite and on the proliferation of MC3T3E1 cells. Journal of biomedical materials research Part A. 2009; 88: 392-400.

49. Knowles JC. Phosphate based glasses for biomedical applications. Journal of Materials Chemistry. 2003; 13: 2395-401. 